\title{
A study of the $\mathrm{H}_{2} \mathrm{SO}_{4}-\mathrm{H}_{3} \mathrm{PO}_{4}-\mathrm{H}_{2} \mathrm{O}-\mathrm{Fe}(\mathrm{III})$ system by cyclic voltammetry
}

\author{
Ya.G. Avdeev,* T.E. Andreeva, A.V. Panova and E.N. Yurasova \\ A.N. Frumkin Institute of Physical Chemistry and Electrochemistry, Russian Academy \\ of Sciences, Leninskii pr. 31, Moscow, 119071 Russian Federation \\ *E-mail: avdeevavdeev@mail.ru
}

\begin{abstract}
The electrochemical behavior of $\mathrm{Fe}(\mathrm{III})$ cations on a platinum electrode in the $\mathrm{H}_{2} \mathrm{SO}_{4}$ $\mathrm{H}_{3} \mathrm{PO}_{4}-\mathrm{H}_{2} \mathrm{O}, \mathrm{H}_{2} \mathrm{SO}_{4}-\mathrm{H}_{2} \mathrm{O}$, and $\mathrm{H}_{3} \mathrm{PO}_{4}-\mathrm{H}_{2} \mathrm{O}$ systems $\left(25-95^{\circ} \mathrm{C}\right)$ has been studied by cyclic voltammetry. The oxidizing ability of the $2.0 \mathrm{M} \mathrm{H}_{2} \mathrm{SO}_{4}+\mathrm{H}_{3} \mathrm{PO}_{4}$ system containing $0.10 \mathrm{M}$ $\mathrm{Fe}(\mathrm{III})$ decreases as the molar fraction of $\mathrm{H}_{3} \mathrm{PO}_{4}$ increases. The observed effect results from the formation of $\mathrm{Fe}$ (III) complexes with phosphate anions that are weaker oxidants than the corresponding hydrate and sulfate complexes. An increase in temperature causes an increase in the oxidizing ability of the $\mathrm{H}_{2} \mathrm{SO}_{4}-\mathrm{H}_{3} \mathrm{PO}_{4}-\mathrm{H}_{2} \mathrm{O}-\mathrm{Fe}$ (III) system. This effect is most pronounced in the $\mathrm{H}_{3} \mathrm{PO}_{4}-\mathrm{H}_{2} \mathrm{O}-\mathrm{Fe}(\mathrm{III})$ system. Addition of $\mathrm{H}_{3} \mathrm{PO}_{4}$ to $\mathrm{H}_{2} \mathrm{SO}_{4}$ solutions converts $\mathrm{Fe}$ (III) cations from hydrate and sulfate complexes to phosphate complexes, which leads to a decrease in their diffusion rate in aqueous acid solutions. The decrease in the diffusion coefficient of $\mathrm{Fe}$ (III) cations is about $1 / 3$ of the initial value. A probable reason for efficient protection of low-carbon steel by triazole-based composite inhibitors in $\mathrm{H}_{3} \mathrm{PO}_{4}$ or its mixtures with $\mathrm{H}_{2} \mathrm{SO}_{4}$ containing $\mathrm{Fe}(\mathrm{III})$, in comparison with similar solutions of $\mathrm{H}_{2} \mathrm{SO}_{4}$ alone, is that phosphate complexes of Fe(III) are formed in these media. They have a lower oxidizing ability and diffusion rate in comparison with aqueous and sulfate complexes of $\mathrm{Fe}(\mathrm{III})$.
\end{abstract}

Key words: corrosion inhibitors, cyclic voltammetry, sulfuric acid, phosphoric acid, redox couple $\mathrm{Fe}(I I I) / \mathrm{Fe}(I I)$, diffusion coefficient.

Received: April 7, 2019. Published: May 5, 2019

doi: $\underline{10.17675 / 2305-6894-2019-8-2-18}$

\section{Introduction}

Etching of steels in solutions of sulfuric acid is accompanied by accumulation of Fe(III) sulfate due to dissolution of scale and oxidation of Fe(II) salts, that are formed in the reactions of scale and metal with the acid, with atmospheric oxygen $[1,2]$. The dissolution of steels in acid solutions containing Fe(III) sulfate occurs not only due to the reaction of iron with an acid:

$$
\mathrm{Fe}+\mathrm{H}_{2} \mathrm{SO}_{4}=\mathrm{FeSO}_{4}+\mathrm{H}_{2} \text {, }
$$

but also due to the parallel reaction of the metal with a Fe(III) salt:

$$
\mathrm{Fe}+\mathrm{Fe}_{2}\left(\mathrm{SO}_{4}\right)_{3}=3 \mathrm{FeSO}_{4} \text {. }
$$


$\mathrm{Fe}$ (III) sulfate can considerably decrease the protective effect of metal corrosion inhibitors added to an etching solution [3].

The adverse effect of $\mathrm{Fe}$ (III) sulfate on the protective effect of corrosion inhibitors toward mild steels can be overcome by replacing sulfuric acid solutions with $\mathrm{H}_{2} \mathrm{SO}_{4}+\mathrm{H}_{3} \mathrm{PO}_{4}$ mixtures containing a formulation of IFKhAN-92 (a 1,2,4-triazole derivative), KNCS and urotropine with a 9:1:400 molar ratio of the components. Such inhibited solutions are resistant against the accumulation of $\mathrm{Fe}(\mathrm{III})$ salts at $\mathrm{H}_{2} \mathrm{SO}_{4}$ concentrations up to $60 \%$ of the total mass of acids in a solution [4].

Previously, the potentiometry method was used to study an $\mathrm{H}_{2} \mathrm{SO}_{4}-\mathrm{H}_{3} \mathrm{PO}_{4}-\mathrm{H}_{2} \mathrm{O}$ system containing $\mathrm{Fe}(\mathrm{III})$ and $\mathrm{Fe}(\mathrm{II})$ cations $[5,6]$. It was shown that a probable reason of the efficient protection of mild steel by triazole-based composite inhibitors in $\mathrm{H}_{3} \mathrm{PO}_{4}$ or its mixtures with $\mathrm{H}_{2} \mathrm{SO}_{4}$ containing $\mathrm{Fe}(\mathrm{III})$, in comparison with similar solutions of $\mathrm{H}_{2} \mathrm{SO}_{4}$ alone, is that phosphate complexes of $\mathrm{Fe}$ (III) are formed in these media. They have lower oxidizing ability in comparison with aqueous and sulfate Fe(III) complexes.

To reach a more detailed understanding of the processes that occur in the $\mathrm{H}_{2} \mathrm{SO}_{4}-$ $\mathrm{H}_{3} \mathrm{PO}_{4}-\mathrm{H}_{2} \mathrm{O}-\mathrm{Fe}(\mathrm{III})$ system and to identify the role of $\mathrm{H}_{3} \mathrm{PO}_{4}$ additives in preserving the protective action of the triazole-based composite inhibitor of in the presence of $\mathrm{Fe}$ (III) salts, it seems necessary to study these solutions by the cyclic voltammetry method (CVA). This method is used quite successfully to study solutions containing Fe(III) and Fe(II) cations alone or their mixtures [7-14]. The effect of HF additives on the characteristics of the $\mathrm{Fe}(\mathrm{III}) / \mathrm{Fe}(\mathrm{II})$ redox process in $\mathrm{H}_{3} \mathrm{PO}_{4}$ solutions was studied by CVA [7]. Addition of hydrogen fluoride reduces the redox potential of the $\mathrm{Fe}(\mathrm{III}) / \mathrm{Fe}(\mathrm{II})$ couple $\left(E_{\mathrm{Fe}(\mathrm{III}) / \mathrm{Fe}(\mathrm{II})}\right)$ in this medium. The observed effects result from the binding of Fe cations into fluoride complexes that are characterized by higher stability compared to iron phosphate complexes.

\section{Experimental}

Solutions were prepared from $\mathrm{H}_{3} \mathrm{PO}_{4}$ and $\mathrm{H}_{2} \mathrm{SO}_{4}$ of "chemically pure" grade and distilled water. $\mathrm{H}_{2} \mathrm{SO}_{4}$ and $\mathrm{H}_{3} \mathrm{PO}_{4}$ solutions containing $\mathrm{Fe}(\mathrm{III})$ salts were obtained by dissolving $\mathrm{Fe}(\mathrm{OH})_{3}$ precipitated with $\mathrm{NaOH}$ ("chemically pure" grade) from a $\mathrm{FeCl}_{3}$ solution, in excess $\mathrm{H}_{2} \mathrm{SO}_{4}$ or $\mathrm{H}_{3} \mathrm{PO}_{4}$. The $\mathrm{Fe}$ (III) chloride solution was prepared from $\mathrm{FeCl}_{3} \cdot 6 \mathrm{H}_{2} \mathrm{O}$ ("pure" grade).

CVA studies were performed using an EL-02.061 potentiostat in a thermostated threeelectrode glass cell with divided electrode spaces. A platinum wire (area $(S) 15.9 \mathrm{~mm}^{2}$ ) served as the working electrode. A silver chloride electrode was used as the reference electrode, and a platinum plate $\left(S=1.5 \mathrm{~cm}^{2}\right)$ was used as the auxiliary electrode. Potential scanning was performed from $1.4 \mathrm{~V}$ to $0.0 \mathrm{~V}$, and then from $0.0 \mathrm{~V}$ to $1.4 \mathrm{~V}$. The scan rates were $0.02,0.05,0.10,0.20$ and $0.40 \mathrm{~V} \cdot \mathrm{s}^{-1}$. The solutions studied were deaerated with argon both before (for $30 \mathrm{~min}$ ) and during an experiment. Before an experiment, the working electrode was degreased with acetone, kept for $3 \mathrm{~min}$ in concentrated $\mathrm{HNO}_{3}$, and washed with distilled water. The temperature $(t)$ range of the studied solutions was $25-95^{\circ} \mathrm{C}$. The accuracy of temperature control was $\pm 1{ }^{\circ} \mathrm{C}$. Electrode potentials are reported versus the standard hydrogen electrode. 


\section{Experimental results and discussion}

The cyclic voltammograms of a Pt electrode in $2.0 \mathrm{M} \mathrm{H}_{2} \mathrm{SO}_{4}+0.05 \mathrm{M} \mathrm{Fe}_{2}\left(\mathrm{SO}_{4}\right)_{3}$ at $25^{\circ} \mathrm{C}$ (Figure 1, Table 1) contain two peaks, the maxima of which are located at $E=0.52-0.55 \mathrm{~V}$ and $0.75-0.81 \mathrm{~V}$, depending on the potential sweep rate $(v)$. The first cathodic peak corresponds to the reduction of Fe(III) cations on the Pt electrode:

$$
\mathrm{Fe}^{3+}+\mathrm{e}^{-}=\mathrm{Fe}^{2+} \text {. }
$$

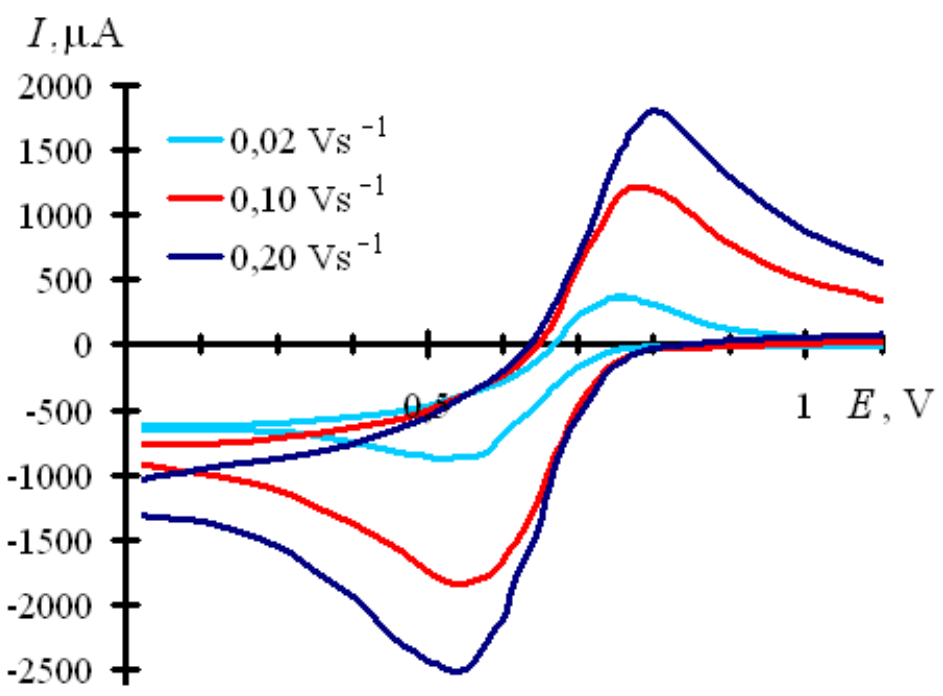

Figure 1. Cyclic voltammograms of platinum electrode in $2.0 \mathrm{M} \mathrm{H}_{2} \mathrm{SO}_{4}+0.05 \mathrm{M} \mathrm{Fe}_{2}\left(\mathrm{SO}_{4}\right)_{3}$ at different scan rates at $25^{\circ} \mathrm{C}$.

Table 1. CVA data of platinum electrode in $2.0 \mathrm{M} \mathrm{H}_{2} \mathrm{SO}_{4}+\mathrm{Fe}_{2}\left(\mathrm{SO}_{4}\right)_{3}$ at $25^{\circ} \mathrm{C}$.

\begin{tabular}{|c|c|c|c|c|c|c|c|}
\hline $\begin{array}{l}\text { Scan rate } \\
(v), V \cdot \mathbf{s}^{-1}\end{array}$ & $\begin{array}{c}\text { Cathodic } \\
\text { peak } \\
\text { potential } \\
\left(E_{p c}\right), V\end{array}$ & $\begin{array}{c}\text { Anodic } \\
\text { peak } \\
\text { potential } \\
\left(E_{\mathrm{pa}}\right), \mathrm{V}\end{array}$ & $\begin{array}{c}\text { Peak } \\
\text { potential } \\
\text { separation } \\
\left(E_{\mathrm{pa}}-E_{\mathrm{pc}}\right), \mathrm{V}\end{array}$ & $\begin{array}{c}\text { Half- } \\
\text { wave } \\
\text { potential } \\
\left(E_{1 / 2}\right), \mathrm{V}\end{array}$ & $\begin{array}{c}\text { Cathodic } \\
\text { peak } \\
\text { current } \\
\left(I_{\mathbf{p c}}\right), \mathbf{m A}\end{array}$ & $\begin{array}{c}\text { Anodic } \\
\text { peak } \\
\text { current } \\
\left(I_{\mathrm{pa}}\right), \mathbf{m A}\end{array}$ & $\begin{array}{c}\text { Peak } \\
\text { current } \\
\text { ratio } \\
\left(I_{\mathrm{pa}} / I_{\mathrm{pc}}\right)\end{array}$ \\
\hline \multicolumn{8}{|c|}{$0.005 \mathrm{M} \mathrm{Fe}_{2}\left(\mathrm{SO}_{4}\right)_{3}$} \\
\hline 0.10 & 0.61 & 0.72 & 0.11 & 0.67 & 0.18 & 0.22 & 1.22 \\
\hline \multicolumn{8}{|c|}{$0.02 \mathrm{M} \mathrm{Fe}_{2}\left(\mathrm{SO}_{4}\right)_{3}$} \\
\hline 0.10 & 0.56 & 0.78 & 0.22 & 0.67 & 0.70 & 0.63 & 0.90 \\
\hline \multicolumn{8}{|c|}{$0.05 \mathrm{M} \mathrm{Fe}_{2}\left(\mathrm{SO}_{4}\right)_{3}$} \\
\hline 0.02 & 0.56 & 0.76 & 0.20 & 0.66 & 0.80 & 0.85 & 1.06 \\
\hline 0.05 & 0.56 & 0.77 & 0.22 & 0.67 & 1.3 & 1.3 & 1.00 \\
\hline 0.10 & 0.55 & 0.78 & 0.23 & 0.67 & 1.8 & 1.7 & 0.94 \\
\hline 0.20 & 0.54 & 0.79 & 0.25 & 0.67 & 2.5 & 2.1 & 0.84 \\
\hline 0.40 & 0.52 & 0.81 & 0.29 & 0.67 & 3.5 & 3.0 & 0.86 \\
\hline
\end{tabular}


The second peak, i.e., the anodic one, corresponds to the oxidation of the $\mathrm{Fe}(\mathrm{II})$ cations formed:

$$
\mathrm{Fe}^{2+}-\mathrm{e}^{-}=\mathrm{Fe}^{3+}
$$

As $v$ increases, the maximum potential of the cathodic peak $\left(E_{\mathrm{pc}}\right)$ decreases, while the anodic peak $\left(E_{\mathrm{pa}}\right)$ grows. The currents in the cathodic and anodic peak maxima $\left(I_{\mathrm{pc}}\right.$ and $\left.I_{\mathrm{pa}}\right)$ also increase with increasing $v$. The system under study is quasi-equilibrium since the criteria for equilibrium systems are not satisfied for it: $E_{\mathrm{pa}}-E_{\mathrm{pc}}>>0.057 \mathrm{~V}$ and $I_{\mathrm{pa}} / I_{\mathrm{pc}} \neq 1$, but both peaks, the cathodic and anodic ones, are present on the voltammograms [15]. The half-wave potential:

$$
E_{1 / 2}=\frac{E_{\mathrm{pc}}+E_{\mathrm{pa}}}{2},
$$

which is often interpreted as the redox potential of a system, does not depend on $v$ within the measurement accuracy limits. A decrease in the content of Fe(III) in the acid solution does not significantly change the nature of cyclic voltammograms (Figure 2, Table 1), but the values of $I_{\mathrm{pc}}$ and $I_{\mathrm{pa}}$ decrease.

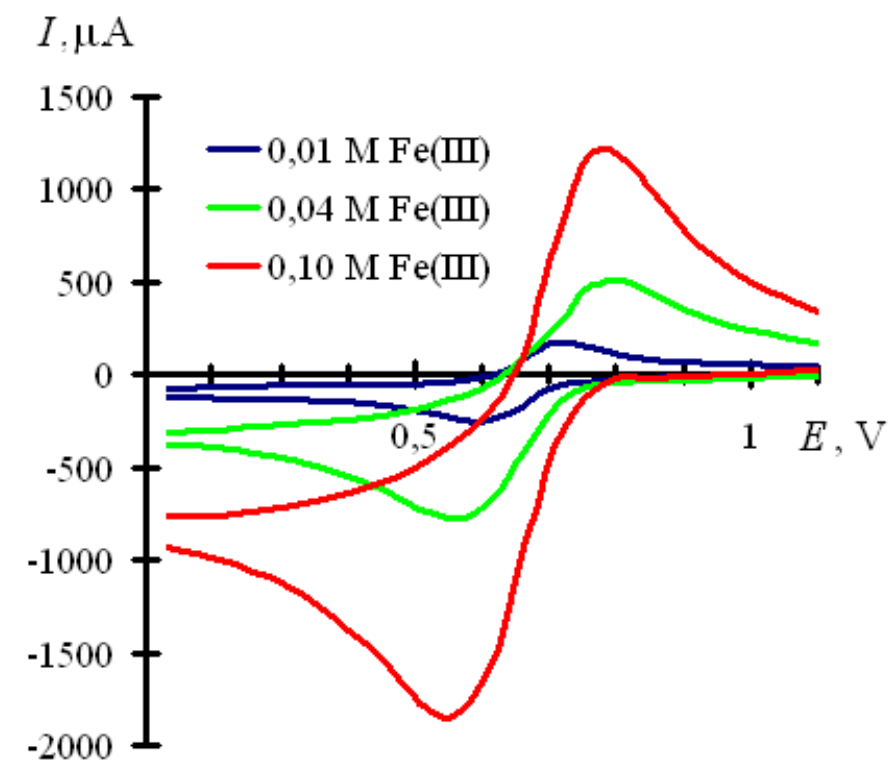

Figure 2. Cyclic voltammograms of platinum electrode in $2.0 \mathrm{M} \mathrm{H}_{2} \mathrm{SO}_{4}+\mathrm{Fe}_{2}\left(\mathrm{SO}_{4}\right)_{3}$ at different concentration of Fe(III). Scan rate: $0.10 \mathrm{Vs}^{-1}$ at $25^{\circ} \mathrm{C}$.

The values of current maxima on the current-potential curves is determined by the Randles-Sevcik equation:

$$
I_{\mathrm{p}}=2.69 \cdot 10^{5} z^{1.5} S C D^{0.5} v^{0.5},
$$

where $2.69 \cdot 10^{5}$ is the equation constant at $25^{\circ} \mathrm{C}$; $z$ is the number of electrons participating in the redox process $(z=1$ for the redox pair Fe (III)/Fe (III)); $S$ is the surface area of the 
electrode $\left(\mathrm{m}^{2}\right) ; C$ is the concentration of the electrochemically active substance $\left(\mathrm{mol} \cdot \mathrm{m}^{-3}\right)$; $D$ is the diffusion coefficient $\left(\mathrm{m}^{2} \cdot \mathrm{s}^{-1}\right)$; and $v$ is the potential sweep rate $\left(\mathrm{V} \cdot \mathrm{s}^{-1}\right)$. The Randles-Sevcik equation describes redox processes that occur in equilibrium systems. However, it is noted that it can be used to describe quasi-reversible and even irreversible systems [15]. The criterion for the applicability of this equation for describing the cathode process in this system is that the $I_{\mathrm{pc}} v s . v^{0.5}$ (Figure 3) and $I_{\mathrm{pc}} v s . C_{\mathrm{Fe}(I I I)}$ plots (Figure 4) should be linear.

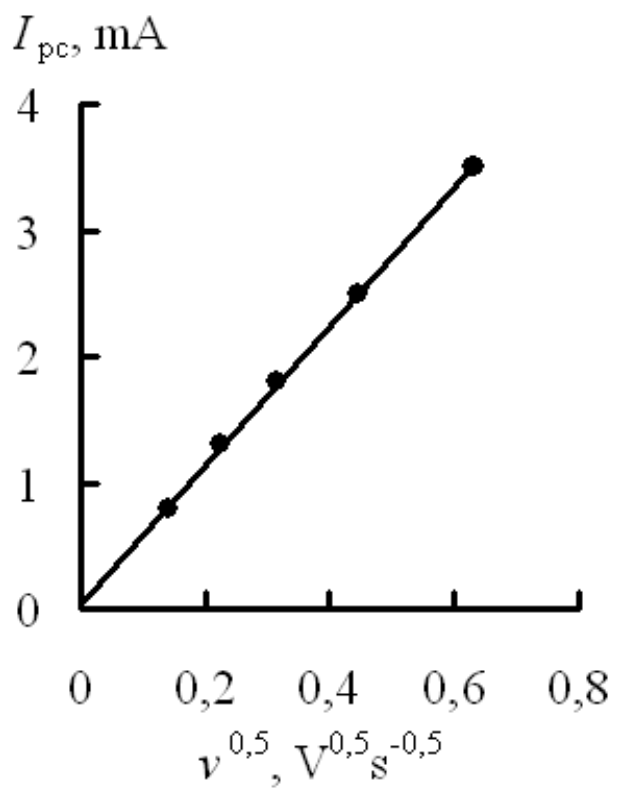

Figure 3. Variation of the cathodic peak current $\left(I_{\mathrm{pc}}\right)$ vs the square root of scan rate $\left(v^{0.5}\right)$ for platinum electrode in $2.0 \mathrm{M} \mathrm{H}_{2} \mathrm{SO}_{4}+0.05 \mathrm{M} \mathrm{Fe}_{2}\left(\mathrm{SO}_{4}\right)_{3} . t=25^{\circ} \mathrm{C}$.

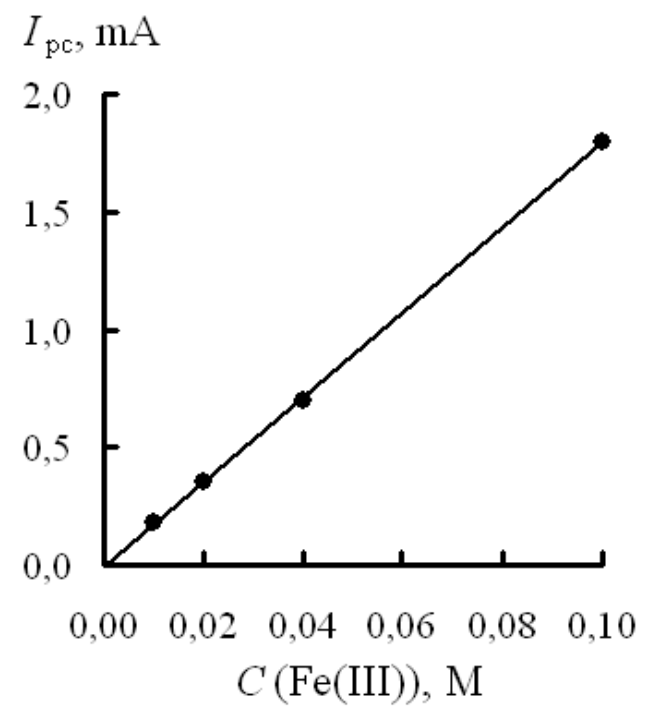

Figure 4. Variation of the cathodic peak current $\left(I_{\mathrm{pc}}\right)$ vs concentration of $\mathrm{Fe}_{2}\left(\mathrm{SO}_{4}\right)_{3}$ for platinum electrode in $2.0 \mathrm{M} \mathrm{H}_{2} \mathrm{SO}_{4}+\mathrm{Fe}_{2}\left(\mathrm{SO}_{4}\right)_{3}$. Scan rate: $0.10 \mathrm{~V} \cdot \mathrm{s}^{-1} \cdot t=25^{\circ} \mathrm{C}$. 
The peaks on the voltammograms of a $\mathrm{Pt}$ electrode in $\mathrm{H}_{2} \mathrm{SO}_{4}+\mathrm{H}_{3} \mathrm{PO}_{4}$ solutions containing $0.10 \mathrm{M} \mathrm{Fe}(\mathrm{III})$ are shifted towards lower potentials in comparison with the solution of $\mathrm{H}_{2} \mathrm{SO}_{4}$ alone, and are characterized by higher non-equilibrium (Figure 5, Table 2). At $25^{\circ} \mathrm{C}, E_{\mathrm{pa}}-E_{\mathrm{pc}}=0.31-0.39 \mathrm{~V}$ in $\mathrm{H}_{2} \mathrm{SO}_{4}+\mathrm{H}_{3} \mathrm{PO}_{4}$ but as small as $0.23 \mathrm{~V}$ in $2.0 \mathrm{M} \mathrm{H}_{2} \mathrm{SO}_{4}$. Already at $10 \% \mathrm{H}_{3} \mathrm{PO}_{4}$ in the solution, the cathodic current decreases. As the content of $\mathrm{H}_{3} \mathrm{PO}_{4}$ in the mixture increases, the value of $E_{1 / 2}$ decreases systematically, indicating a decrease in the oxidative capability of the system. The lowest value $E_{1 / 2}=0.41 \mathrm{~V}$ is observed in $2.0 \mathrm{M} \mathrm{H}_{3} \mathrm{PO}_{4}$, against $E_{1 / 2}=0.67 \mathrm{~V}$ in $2.0 \mathrm{M} \mathrm{H}_{2} \mathrm{SO}_{4}$.

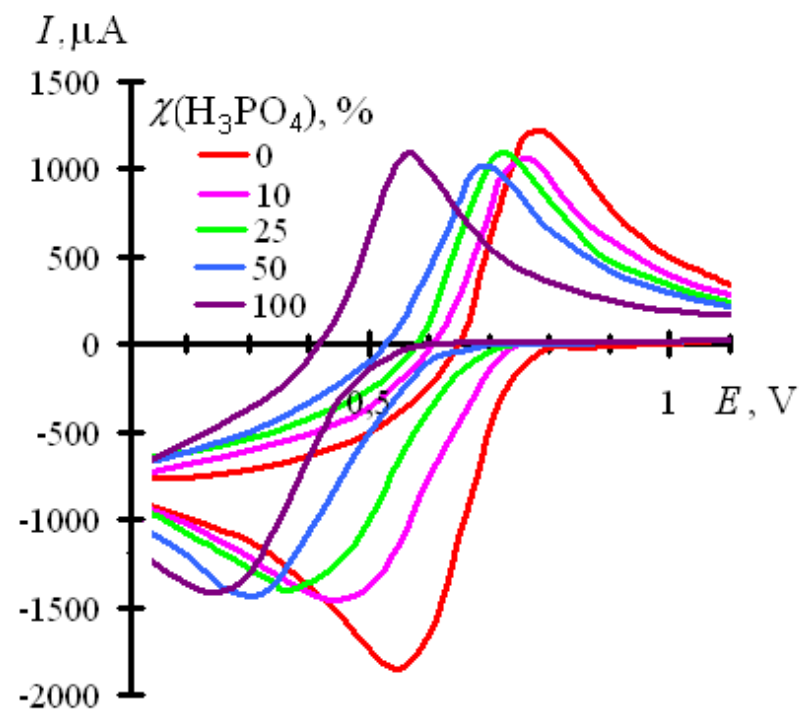

Figure 5. Cyclic voltammograms of platinum electrode in $\mathrm{H}_{2} \mathrm{SO}_{4}+\mathrm{H}_{3} \mathrm{PO}_{4}+0.10 \mathrm{M} \mathrm{Fe}$ (III) $\left(25^{\circ} \mathrm{C}\right)$ at different concentration of $\mathrm{H}_{3} \mathrm{PO}_{4}$. Scan rate: $0.10 \mathrm{~V} \cdot \mathrm{s}^{-1}$ at $25^{\circ} \mathrm{C}$.

Other conditions being equal, an increase in temperature $(t)$ results in an increase in the height of the cathodic and anodic peaks on the voltammograms of acid solutions containing $\mathrm{Fe}$ (III) (Figure 6, Table 2). An increase in $E_{1 / 2}$ is observed. The $E_{1 / 2}$ values in $2.0 \mathrm{M} \mathrm{H}_{3} \mathrm{PO}_{4}+0.10 \mathrm{M} \mathrm{FePO}_{4}$ are least sensitive to an increase in temperature. Comparison of the $E_{1 / 2}$ values obtained from these cyclic voltammograms with $E_{\mathrm{Fe}(\mathrm{III}) / \mathrm{Fe}(\mathrm{II})}$ determined in potentiometric studies [5] shows their good agreement. In $2.0 \mathrm{M} \mathrm{H}_{2} \mathrm{SO}_{4}+0.05 \mathrm{M}$ $\mathrm{Fe}_{2}\left(\mathrm{SO}_{4}\right)_{3}, E_{1 / 2}=0.67-0.76 \mathrm{~V}, E_{\mathrm{Fe}(\mathrm{III}) / \mathrm{Fe}(\mathrm{II})}=0.66-0.75 \mathrm{~V}$; in $2.0 \mathrm{M} \mathrm{H}_{3} \mathrm{PO}_{4}+0.10 \mathrm{M} \mathrm{FePO}_{4}$, $E_{1 / 2}=0.41-0.46 \mathrm{~V}, E_{\mathrm{Fe}(\mathrm{III}) / \mathrm{Fe}(\mathrm{II})}=0.44-0.46 \mathrm{~V}$; in $1.0 \mathrm{M} \mathrm{H}_{2} \mathrm{SO}_{4}+1.0 \mathrm{M} \mathrm{H}_{3} \mathrm{PO}_{4}+0.025 \mathrm{M}$ $\mathrm{Fe}_{2}\left(\mathrm{SO}_{4}\right)_{3}+0.50 \mathrm{M} \mathrm{FePO}, E_{1 / 2}=0.51-0.62 \mathrm{~V}, E_{\mathrm{Fe}(\mathrm{III}) / \mathrm{Fe}(\mathrm{II})}=0.55-0.60 \mathrm{~V}$. It should be noted that in [7] larger quantitative differences are observed between the potentials of the $\mathrm{Fe}(\mathrm{III}) / \mathrm{Fe}(\mathrm{II})$ redox pair obtained from the results of parallel measurements by CVA and potentiometry. 
Table 2. CVA data of platinum electrode in $\mathrm{H}_{2} \mathrm{SO}_{4}+\mathrm{H}_{3} \mathrm{PO}_{4}+\mathrm{Fe}_{2}\left(\mathrm{SO}_{4}\right)_{3}+\mathrm{FePO}_{4}$ system at different temperatures. Scan rate: $0.10 \mathrm{~V} \cdot \mathrm{s}^{-1}$.

\begin{tabular}{|c|c|c|c|c|c|c|c|}
\hline$\underset{{ }^{\circ} \mathrm{C}}{\text { Temp. }}(t)$ & $\begin{array}{l}\text { Cathodic } \\
\text { peak } \\
\text { potential } \\
\left(E_{\text {pc }}\right), \mathrm{V}\end{array}$ & $\begin{array}{c}\text { Anodic } \\
\text { peak } \\
\text { potential } \\
\left(E_{\text {pa }}\right), \mathrm{V}\end{array}$ & $\begin{array}{c}\text { Peak } \\
\text { potential } \\
\text { separation } \\
\left(E_{\mathrm{pa}}-E_{\mathrm{pc}}\right), \mathbf{V}\end{array}$ & $\begin{array}{c}\text { Half- } \\
\text { wave } \\
\text { potential } \\
\left(E_{1 / 2}\right), \mathrm{V}\end{array}$ & $\begin{array}{c}\text { Cathodic } \\
\text { peak } \\
\text { current } \\
\left(I_{\mathrm{pc}}\right), \mathbf{m A}\end{array}$ & $\begin{array}{c}\text { Anodic } \\
\text { peak } \\
\text { current } \\
\left(I_{\text {pa }}\right), \text { mA }\end{array}$ & $\begin{array}{c}\text { Peak } \\
\text { current } \\
\text { ratio } \\
\left(I_{\mathrm{pa}} / I_{\mathrm{pc}}\right)\end{array}$ \\
\hline \multicolumn{8}{|c|}{$2.0 \mathrm{M} \mathrm{H}_{2} \mathrm{SO}_{4}+0.05 \mathrm{M} \mathrm{Fe}_{2}\left(\mathrm{SO}_{4}\right)_{3}$} \\
\hline 25 & 0.55 & 0.78 & 0.23 & 0.67 & 1.8 & 1.7 & 0.94 \\
\hline 40 & 0.63 & 0.75 & 0.12 & 0.69 & 2.6 & 2.8 & 1.08 \\
\hline 60 & 0.68 & 0.77 & 0.09 & 0.73 & 3.4 & 3.1 & 0.91 \\
\hline 80 & 0.70 & 0.79 & 0.09 & 0.75 & 3.8 & 3.2 & 0.84 \\
\hline 95 & 0.71 & 0.80 & 0.09 & 0.76 & 4.3 & 4.0 & 0.93 \\
\hline \multicolumn{8}{|c|}{$1.8 \mathrm{M} \mathrm{H}_{2} \mathrm{SO}_{4}+0.2 \mathrm{M} \mathrm{H}_{3} \mathrm{PO}_{4}+0.045 \mathrm{M} \mathrm{Fe}_{2}\left(\mathrm{SO}_{4}\right)_{3}+0.01 \mathrm{M} \mathrm{FePO}_{4}$} \\
\hline 25 & 0.45 & 0.76 & 0.31 & 0.61 & 1.4 & 1.4 & 1.00 \\
\hline \multicolumn{8}{|c|}{$1.5 \mathrm{M} \mathrm{H}_{2} \mathrm{SO}_{4}+0.5 \mathrm{M} \mathrm{H}_{3} \mathrm{PO}_{4}+0.0375 \mathrm{M} \mathrm{Fe}_{2}\left(\mathrm{SO}_{4}\right)_{3}+0.025 \mathrm{M} \mathrm{FePO}_{4}$} \\
\hline 25 & 0.36 & 0.73 & 0.37 & 0.55 & 1.4 & 1.4 & 1.00 \\
\hline \multicolumn{8}{|c|}{ 1.0 $\mathrm{M} \mathrm{H}_{2} \mathrm{SO}_{4}+1.0 \mathrm{M} \mathrm{H}_{3} \mathrm{PO}_{4}+0.025 \mathrm{MFe}_{2}\left(\mathrm{SO}_{4}\right)_{3}+0.50 \mathrm{M} \mathrm{FePO}_{4}$} \\
\hline 25 & 0.31 & 0.70 & 0.39 & 0.51 & 1.4 & 0.87 & 0.62 \\
\hline 40 & 0.34 & 0.70 & 0.36 & 0.52 & 1.8 & 1.4 & 0.78 \\
\hline 60 & 0.48 & 0.66 & 0.18 & 0.57 & 2.3 & 2.5 & 1.09 \\
\hline 80 & 0.54 & 0.65 & 0.11 & 0.60 & 3.4 & 3.5 & 1.03 \\
\hline 95 & 0.57 & 0.67 & 0.10 & 0.62 & 3.9 & 4.2 & 1.08 \\
\hline \multicolumn{8}{|c|}{$2.0 \mathrm{M} \mathrm{H}_{3} \mathrm{PO}_{4}+0.10 \mathrm{M} \mathrm{FePO}_{4}$} \\
\hline 25 & 0.25 & 0.56 & 0.31 & 0.41 & 1.4 & 0.99 & 0.71 \\
\hline 40 & 0.28 & 0.54 & 0.26 & 0.41 & 1.8 & 1.4 & 0.78 \\
\hline 60 & 0.35 & 0.52 & 0.17 & 0.44 & 2.4 & 2.3 & 0.96 \\
\hline 80 & 0.38 & 0.53 & 0.15 & 0.46 & 3.1 & 2.9 & 0.94 \\
\hline 95 & 0.39 & 0.52 & 0.13 & 0.46 & 3.7 & 3.3 & 0.89 \\
\hline
\end{tabular}




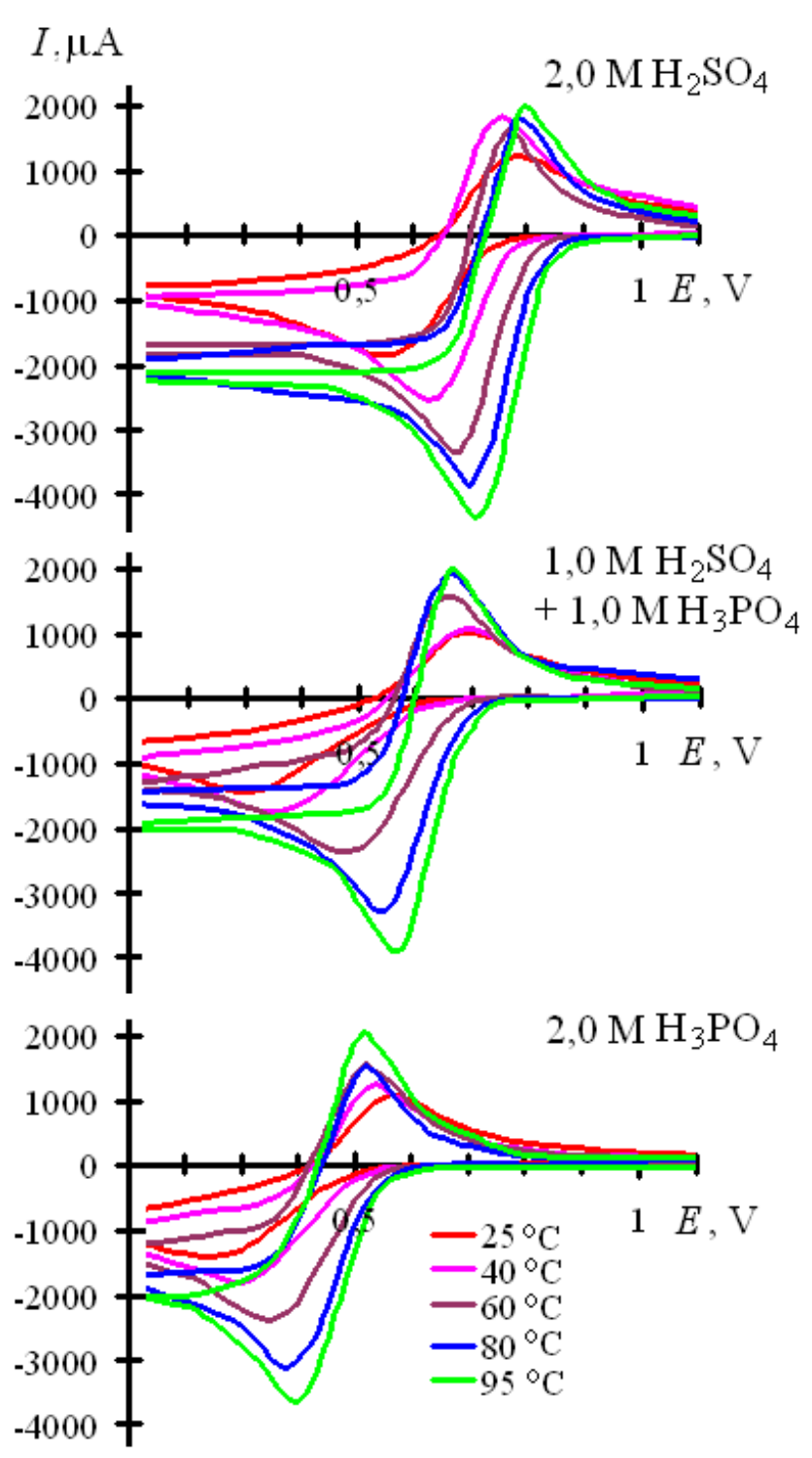

Figure 6. Cyclic voltammograms of platinum electrode in $\mathrm{H}_{2} \mathrm{SO}_{4}+\mathrm{H}_{3} \mathrm{PO}_{4}+0.10 \mathrm{M} \mathrm{Fe}(\mathrm{III})$ at different temperatures. Scan rate: $0.10 \mathrm{~V} \cdot \mathrm{s}^{-1}$.

It appears important to estimate the effect of $\mathrm{H}_{3} \mathrm{PO}_{4}$ addition on the diffusion rate of Fe(III) cations in the media being studied. The results that we presented above show the possibility of using the Randles-Sevcik equation for describing the cathodic process in the systems we are studying. The $I_{\mathrm{pc}}$ values obtained experimentally allowed us to calculate the $D_{\text {Fe (III) }}$ parameter by the Randles-Sevcik equation (Figure 7). The values of the diffusion coefficient of $\mathrm{Fe}(\mathrm{III})$ cations show that already at $10 \% \mathrm{H}_{3} \mathrm{PO}_{4}$ in the system, it decreases by about $1 / 3$ compared to the value observed in $\mathrm{H}_{2} \mathrm{SO}_{4}$. The average $D_{\mathrm{Fe}(\mathrm{III})}$ value that we obtained in $2.0 \mathrm{M} \mathrm{H}_{3} \mathrm{PO}_{4}$ is $110 \mu \mathrm{m}^{2} \cdot \mathrm{s}^{-1}$, which is close to $D_{\mathrm{Fe}(\mathrm{III})}=120 \mu \mathrm{m}^{2} \cdot \mathrm{s}^{-1}$ in $1.0 \mathrm{M}$ $\mathrm{H}_{3} \mathrm{PO}_{4}\left(20^{\circ} \mathrm{C}\right)$ according to [7]. 


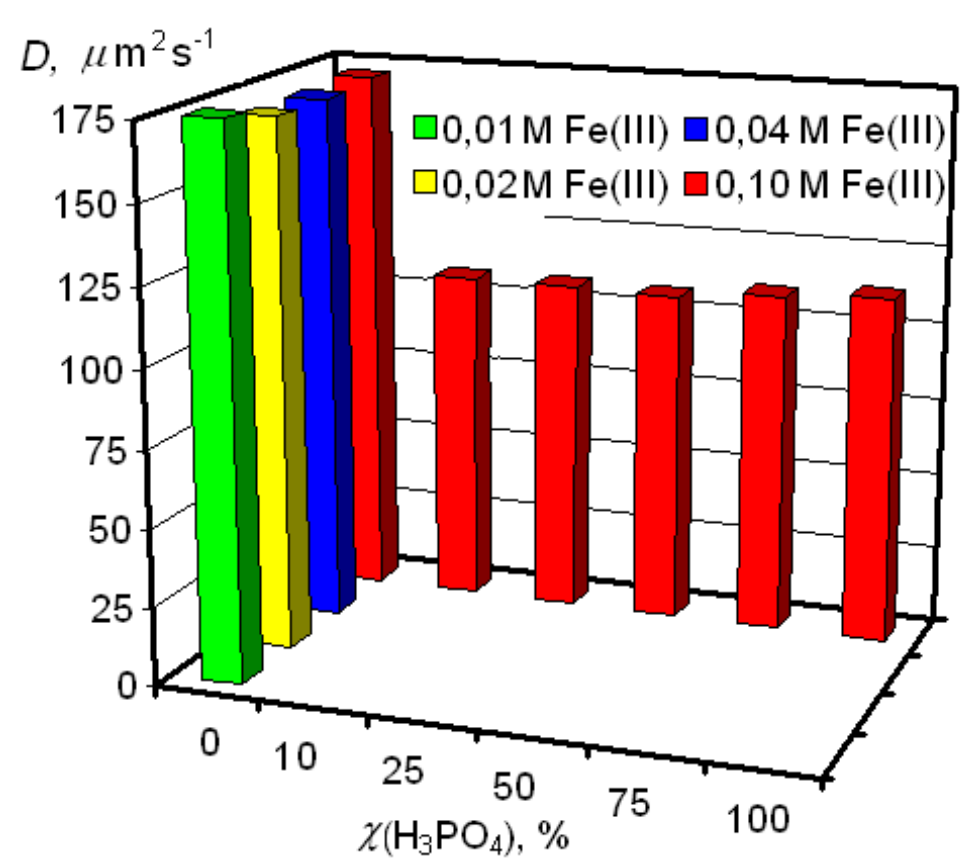

Figure 7. Effect of $\mathrm{H}_{3} \mathrm{PO}_{4}$ and $\mathrm{Fe}(\mathrm{III})$ concentrations in $\mathrm{H}_{2} \mathrm{SO}_{4}+\mathrm{H}_{3} \mathrm{PO}_{4}+\mathrm{Fe}(\mathrm{III})$ system on the diffusion coefficient of the Fe(III) cation. $t=25^{\circ} \mathrm{C}$.

Thus, the use of CVA to study $\mathrm{H}_{2} \mathrm{SO}_{4}+\mathrm{H}_{3} \mathrm{PO}_{4}$ mixtures containing $\mathrm{Fe}$ (III) allowed us to find additional reasons of the preservation of the protective effect of the IFKhAN-92 based composite inhibitor in the corrosion of steels in these media. Phosphate ions bind the strong oxidant additionally present in the solution, i.e., $\mathrm{Fe}$ (III) cations, into strong complexes. These phosphate complexes have lower oxidizing ability and mobility than aqueous and sulfate complexes of $\mathrm{Fe}(\mathrm{III})$. Addition of $\mathrm{H}_{3} \mathrm{PO}_{4}$ affects the thermodynamic properties of the corrosive environment by reducing its oxidative capability. This additive also changes the kinetic parameters of the reduction of Fe(III) cations on steel that occurs in diffusion mode [16]. A decrease in the diffusion rate of Fe(III) cations should slow down their reduction. Apparently, such a complex effect should be sufficient to enable the composite inhibitor based on IFKhAN-92 not only to slow down the reduction of protons but also suppress the reduction of Fe(III) cations. At the same time, the IFKhAN-92 inhibitor itself plays an important role in the observed effect. This compound can form monomolecular and polymolecular protective layers on the surface of metals in acid solutions. These layers are strongly bound to the metal surface by chemical bonds [17, 18], which allows the maximum protective effect to be provided in such strongly corrosive environments as acids.

\section{Conclusions}

1. The oxidizing capability of the $\mathrm{H}_{2} \mathrm{SO}_{4}-\mathrm{H}_{3} \mathrm{PO}_{4}-\mathrm{H}_{2} \mathrm{O}$ system containing $\mathrm{Fe}$ (III) and $\mathrm{Fe}$ (II) decreases as the relative content of $\mathrm{H}_{3} \mathrm{PO}_{4}$ increases. The observed effect results from the formation of $\mathrm{Fe}$ (III) complexes with phosphate anions that are weaker oxidants than the corresponding hydrate and sulfate complexes. 
2. Addition of $\mathrm{H}_{3} \mathrm{PO}_{4}$ to $\mathrm{H}_{2} \mathrm{SO}_{4}$ solutions converts $\mathrm{Fe}$ (III) cations from hydrate and sulfate complexes to phosphate complexes, which leads to a decrease in their diffusion rate in aqueous acid solutions. The decrease in the diffusion coefficient of $\mathrm{Fe}$ (III) cations is about $1 / 3$ of the initial value.

3. The oxidizing ability of Fe(III) phosphate complexes is lower than that of its aqueous and sulfate complexes. These effects explain the efficient protection of low-carbon steel by composite inhibitors based on triazoles in $\mathrm{H}_{3} \mathrm{PO}_{4}$ or in its mixtures with $\mathrm{H}_{2} \mathrm{SO}_{4}$ containing $\mathrm{Fe}(\mathrm{III})$ in comparison with similar solutions of $\mathrm{H}_{2} \mathrm{SO}_{4}$ alone.

\section{Acknowledgments}

The study was carried out within the framework of the Program of Basic Scientific Research of the State Academies of Sciences for 2013-2020. The topic "Development of the fundamental scientific basis of the protective effect of inhibitors of metal corrosion in gas and condensed media, nanocomposites, paintwork and conversion coatings" (state registration number AAAA-A18-118121090043-0).

\section{References}

1. L.I. Antropov, E.M. Makushin and V.F. Panasenko, Ingibitory korrozii metallov (Metal Corrosion Inhibitors), Tehnika, Kiev, 1981, 58-61 (in Russian).

2. Ya.G. Avdeev, I.G. Gorichev and A.Yu. Luchkin, Effect of IFKhAN-92 inhibitor on scale removal during sulfuric acid pickling of steel, Int. J. Corros. Scale Inhib., 2012, 1, no. 1, 26-37. doi: 10.17675/2305-6894-2012-1-1-026-037

3. Ya.G. Avdeev, O.A. Kireeva, Yu.I. Kuznetsov and I.G. Gorichev, Effect of the anionic composition of acidic solutions containing Fe(III) on the protection of low-carbon steel by a triazole inhibitor, Int. J. Corros. Scale Inhib., 2016, 5, no. 4, 333-346. doi: 10.17675/2305-6894-2016-5-4-4

4. Ya.G. Avdeev, O.A. Kireeva, D.S. Kuznetsov and Yu.I. Kuznetsov, The Influence of Hexamethylenetetramine on the Corrosion Inhibition of Low Carbon Steel in Mixtures of Sulfurous and Phosphorus Acids Containing Fe(III) by IFKhAN-92 and KNCS Composition, Prot. Met. Phys. Chem. Surf., 2018, 54, no. 7, 1298-1304. doi: 10.1134/S2070205118070055

5. Ya.G. Avdeev, T.E. Andreeva and Yu.I. Kuznetsov, A potentiometric study of an $\mathrm{H}_{2} \mathrm{SO}_{4}-\mathrm{H}_{3} \mathrm{PO}_{4}-\mathrm{H}_{2} \mathrm{O}$ system containing $\mathrm{Fe}(\mathrm{III})$ and $\mathrm{Fe}(\mathrm{II})$ cations, Int. J. Corros. Scale Inhib., 2018, 7, no. 3, 366-375. doi: 10.17675/2305-6894-2018-7-3-7

6. Ya.G. Avdeev, T.E. Andreeva, A.V. Panova and Yu.I. Kuznetsov, Effect of anionic composition of solutions of mineral acids containing $\mathrm{Fe}(\mathrm{III})$ on their oxidizing properties, Int. J. Corros. Scale Inhib., 2019, 8, no. 1, 139-149. doi: 10.17675/23056894-2019-8-1-12

7. B. Belqat, A. Laghzizil, K. Elkacimi, A. Bouhaouss and S. Belcadi, Fluoride effect on the electrochemical behaviour of the $\mathrm{Fe}(\mathrm{III}) / \mathrm{Fe}(\mathrm{II})$ system in $\mathrm{H}_{3} \mathrm{PO}_{4}+\mathrm{H}_{2} \mathrm{O}+\mathrm{HF}, J$. Fluorine Chem., 2000, 105, 1-5. doi: 10.1016/S0022-1139(00)00256-6 
8. H.M. Naseem Akhtar, A.A. Shaikh and M.Q. Ehsan, Cyclic Voltammetric Study of the Redox Behavior of $\mathrm{Fe}(\mathrm{II}) / \mathrm{Fe}(\mathrm{III})$ Systems Forming During the Oxidation of $\mathrm{Fe}(\mathrm{II})$ Complexes with Saccharin and with Saccharin and 1,10-Phenanthroline, Russ. J. Electrochem., 2008, 44, no. 12, 1403-1408. doi: 10.1134/S102319350812015X

9. M.H. Bridge, E. Williams, M.E.G. Lyons, K.F. Tipton and W. Linert, Electrochemical investigation into the redox activity of $\mathrm{Fe}(\mathrm{II}) / \mathrm{Fe}(\mathrm{III})$ in the presence of nicotine and possible relations to neurodegenerative diseases, Biochim. Biophys. Acta, 2004, 1690, 77-84. doi:10.1016/j.bbadis.2004.05.007

10. J. Vatrál, R. Boca, W. Linert, Electrochemical investigation of the redox couple $\mathrm{Fe}(\mathrm{III}) / \mathrm{Fe}(\mathrm{II})$ in the presence of amino acids and neurotransmitters, Electrochim. Acta, 2014, 145, 53-63. doi: 10.1016/j.electacta.2014.08.079

11. M.M. Radhi, E.A. Jaffar Al-Mulla and W.T. Tan, Electrochemical haracterization of the redox couple of $\mathrm{Fe}(\mathrm{III}) / \mathrm{Fe}(\mathrm{II})$ mediated by grafted polymer electrode, Res. Chem. Intermed., 2012, 38, no. 9, 179-192. doi: $10.1007 / \mathrm{s} 11164-012-0954-6$

12. Q. Xu, T.S. Zhao, L. Wei, C. Zhang and X.L. Zhou, Electrochemical characteristics and transport properties of $\mathrm{Fe}(\mathrm{II}) / \mathrm{Fe}(\mathrm{III})$ redox couple in a non-aqueous reline deep eutectic solvent, Electrochim. Acta, 2015, 154, 462-467. doi: 10.1016/j.electacta.2014.12.061

13. Y.-W.D. Chen, K.S.V. Santhanam and A.J. Bard, Solution Redox Couples for Electrochemical Energy Storage: I. Iron (III)-Iron (II) Complexes with OPhenanthroline and Related Ligands, J. Electrochem. Soc., 1981, 128, no. 7, 14601467. doi: $10.1149 / 1.2127663$

14. Y.H. Wen, H.M. Zhang, P. Qian, H.T. Zhou, P. Zhao, B.L. Yi and Y.S. Yang, Studies on Iron $\left(\mathrm{Fe}^{3+} / \mathrm{Fe}^{2+}\right)-$ Complex/Bromine $\left(\mathrm{Br}_{2} / \mathrm{Br}^{-}\right)$Redox Flow Cell in Sodium Acetate Solution, J. Electrochem. Soc., 2006, 153, no. 5, A929-A934. doi: 10.1149/1.2186040

15. J.A. Plambeck, Electroanalytical chemistry: Basic Principles and Applications, John Wiley \& Sons, New York, Chichester, Brisbane, Toronto, Singapore, 1982, 404.

16. Ya.G. Avdeev, M.V. Tyurina and Yu.I. Kuznetsov, Zashchita nizkouglerodistoy stali v rastvorakh fosfornoy kisloty ingibitorom IFKhAN-92. Ch. 3. Vliyaniye kationov zheleza (Protection of mild steel in solutions of phosphoric acid by inhibitor IFKhAN92. Part 3. Effect of iron cations.), Korroz.: mater., zashch., 2014, no. 1, 18-25 (in Russian).

17. Ya.G. Avdeev, A.Yu. Luchkin and Yu.I. Kuznetsov, Adsorption of IFKhAN-92 Corrosion Inhibitor on Low Carbon Steel from Hydrochloric Acid Solution, Prot. Met. Phys. Chem. Surf., 2013, 49, no. 7, 865-868. doi: 10.1134/S2070205113070046

18. Ya.G. Avdeev, A.Yu. Luchkin, M.V. Tyurina and Yu.I. Kuznetsov, Adsorption of IFKhAN-92 Corrosion Inhibitor From Acidic Phosphate Solution on Low Carbon Steel, Prot. Met. Phys. Chem. Surf., 2017, 53, no. 7, 1247-1251. doi: $\underline{10.1134 / \mathrm{S} 2070205117070048}$ 